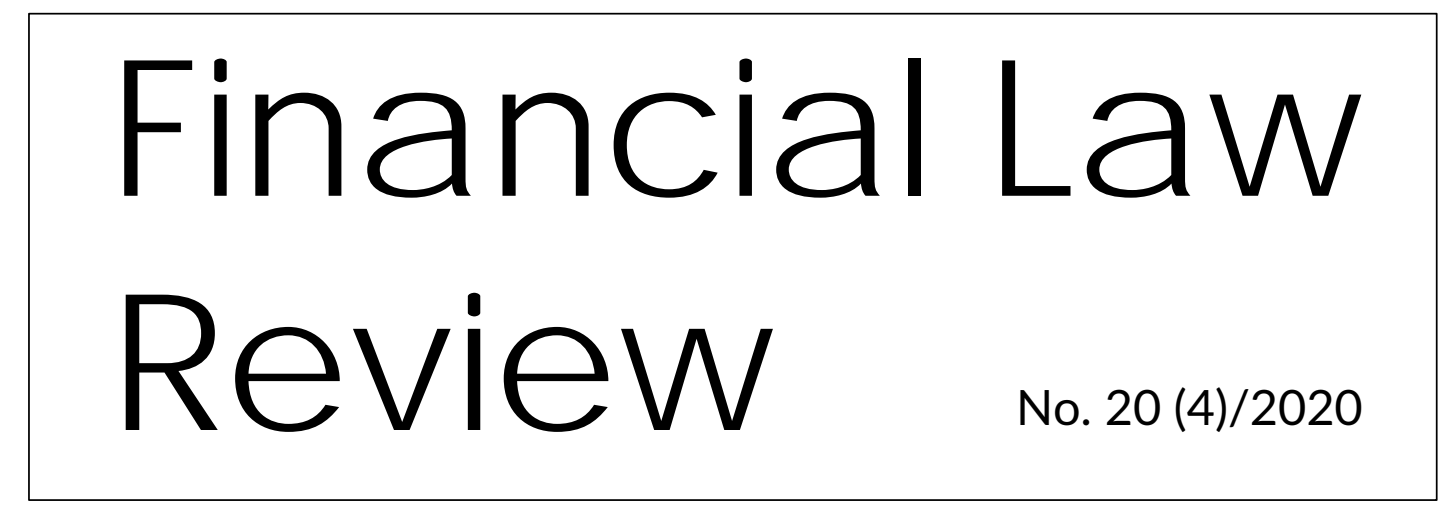

UNIVERSITY OF GDAŃSK • MASARYK UNIVERSITY • PAVEL JOZEF ŠAFÁRIK UNIVERSITY • UNIVERSITY OF VORONEZH http://www.ejoumals.eu/FLR

\title{
THE DEVELOPMENT OF REAL PROPERTY TAX - THE CASE OF CITY OF KOŠICE ${ }^{1}$
}

\begin{abstract}
The paper is focused on the field of real property taxation in Slovakia, from a legal-budgetary point of view, at the local level (the City of Košice). The scientific goal of the paper is to assess the development in the total revenue, tax revenue and revenue from real property taxation in component-wise structure (revenue from the taxation of land, buildings and flats and nonresidential premises) within the period from 2005 to 2019, as well as the search for causal relations
\end{abstract}

\footnotetext{
* JUDr. Anna Vartašová, PhD. is a researcher at Pavol Jozef Šafárik University in Košice, Faculty of Law, Department of Financial Law, Tax Law, and Economics. Her specialisations are local taxes, direct taxation, and tax administration. She is the author of more than 60 reviewed scientific outputs in the form of articles in journals, chapters in monographs, and conference papers. She is a member of International Property Tax Institute, Toronto, and Information and Organization Centre for the Research on the Public Finances and Tax Law in the Countries of Central and Eastern Europe, too. Contact: anna.romanova@upjs.sk, ORCID: 0000-0002-1366-0134.

** Ing. Karolína Červená, PhD. works as an assistant professor at the Department of Financial Law, Tax Law, and Economics at Faculty of Law, Pavol Jozef Šafárik University in Košice. Within her study she specialised at branch and sector economies where she researched macro and microeconomic view on functioning of industrial sectors in Slovak republic. She is an author/coauthor of numerous scientific publications. She deals with economic issues regarding finance, accounting and taxes. Her effort is to link the legal and economic perspective on the issues of taxation in the context of current globalisation. She is a member of Information and Organization Centre for the Research on the Public Finances and Tax Law in the Countries of Central and Eastern Europe. Contact: karolina.cervena@upjs.sk, ORCID: 0000-0003-4900-6510.

${ }^{1}$ This work was supported by the Slovak Research and Development Agency uder the Contract no. APVV-19-0124.
} 
between legislation and reported revenue. Within the first stage of targeted research; the authors applied standard scientific methods and procedures, namely the study and analysis of legislation (selected laws and generally binding regulations), the database of available and requested numerical data and information, which were provided by the selected subject of local self-government - the City of Košice; in the second stage of targeted research the authors created through abstraction, comparison, induction and deduction their own results and conclusions, which are presented in this paper in textual and graphical forms.

Key words: tax law, local taxation, real property tax, municipal finance.

JEL Classification: K34

\section{Introduction}

Historically, in the broadest context, the administration as part of public governance ensures communication between citizens and the government at the state and local levels, using economic (e.g. tax), legal (e.g. enforcement), political (e.g. elections) instruments, while its permanent task is to function in the most efficient way under the given conditions [Bolfíková 2017]. An important financial instrument at the local level is the authority for levying local taxes, which can be defined in various ways [Radvan 2012: 15], and represent one of the sources of revenue needed for provision of administration - operation of local self-government. As they represent own source of financing for the local government, they contribute to the strengthening of the local government's fiscal autonomy (see Juchniewicz, 2017: 34). In the Slovak Republic, local taxes from the point of view of local self-government (municipalities, cities) have gained importance in the context of the need to obtain their own financial resources, which is one of the principles of fiscal decentralization [Nižňanský, Cibáková, Hamalová 2014; Bryson, Cornia, Wheeler 2004, Bobáková 2016: 36; Maličká 2019a]. We consider the real property tax as the most significant tax of all local taxes ${ }^{2}$, especially in terms of budget (it represents $62.82 \%$ of revenues from all local taxes and fees, and also $6.76 \%$ of total municipalities' revenue 2018), but also in terms of municipalities scope of authority in relation to their levying. The framework regulation of this tax is included in the Act No. 582/2004 Coll. on local taxes and local fees for municipal waste and small construction waste (hereinafter referred to as the "Local Tax Act"), which provides municipalities with certain authority in their levying and definition. The real property tax in the Slovak Republic consists of the land tax, the buildings tax and the tax on flats and non-residential premises in residential buildings. The

\footnotetext{
2 The situation is similar in Poland [Etel 2019: 76; Pahl, Mariański 2020: 420] as well as in the Czech Republic [Radvan 2017:12].
} 
Local Tax Act defines, for these components of real property tax, terms such as taxpayer, subject of the tax, tax base, tax rate, method of calculating the tax and joint exemptions and reductions, origin and termination of the tax liability and questions of tax administration. It also delegates to the municipality the authority to levy (by a Generally Binding Regulation - GBR) a tax, set its rate (within legal limits), optional exemptions, and a method of payment of tax in instalments and, within the minimum framework, a tax base ${ }^{3}$. Each municipality, as a tax administrator, may adjust these elements according to its needs, while the most important tool for regulating the revenue from real property tax is a variably adjustable differentiated tax rate, for individual types of land, buildings and flats and non-residential premises, or ways of their use, also differently for different parts of municipalities, and as a result, these partial rates often differ significantly within an individual municipality [Vartašová, Červená 2019: 56].

The authors deal with real property taxation in general, but also analyze the development in the real property taxation in a particular entity - the City of Košice, from a legal and budgetary point of view. The question of the budget's revenue structure and its analysis has been discussed also in other papers [e.g. Králik 2014; Balážová, Papcunová, Tej 2016; Románová, Červená 2017; Papcunová, Nováková 2019; Bobáková, Rožová 2019; Maličká 2019b]. The overall scientific goal of this paper is to assess the development in total revenue, tax revenue and especially revenue from real property taxation in a componentwise structure (revenue from the taxation of land, buildings and housing and nonresidential premises) within the period from 2005 to 2019 (and the budget plan for 2020), and the search for causal relations between the legislation and reported real property tax revenues. The authors, within the first stage of the targeted research (first partial target), applied standard scientific methods and procedures, namely the study and analysis of legislation, database of available and requested numerical data and information, which were provided by the selected subject of territorial self-government - the City of Košice; within the second stage of the targeted research (second partial target) the authors created, through abstraction, comparison, induction and deduction, their own results and conclusions, which are presented in this paper in textual and graphical forms.

\footnotetext{
${ }^{3}$ Specifically for building plots and, in exceptional cases, for arable land, hop-fields, vineyards, orchards, permanent grassland, forest plots and ponds.
} 


\section{Real property tax - the development of the legislation in the Slovak Republic}

The current concept of real property tax has been applied since 2005 , when, on the basis of the Local Tax Act, the former system of local levies was replaced by local taxes and the state's real property tax applied until then became the basic local tax imposed by municipalities. The original real property tax was regulated by the Act of the Slovak National Council No. 317/1992 Coll. on real property tax and this regulation was mostly transferred into the new regulation. The real property tax according to Act No. 317/1992 Coll. represented the unification of the relatively fragmented legal regulations of the state's real property taxation in the Czech and Slovak Federative Republic, as it replaced or repealed the provisions of up to nine legal regulations ${ }^{4}$, where the basis of the system of real property taxation was represented by the Act of the Federal Assembly of the Czechoslovak Socialist Republic No. 172/1988 Coll. on agricultural tax, as amended, which regulated the land tax (preceded by Act No. 103/1974 Coll. On agricultural tax, Act No. 112/1966 Coll. On agricultural tax, Act No. 50/1959 Coll. On agricultural tax, Act No. 77/1952 Coll., on agricultural tax and Act No. 49/1948 Coll., On agricultural tax) and the Act of the National Assembly of the Czechoslovak Socialist Republic No. 143/1961 Coll. on house tax as amended by Act of the Slovak National Council No. 134/1974 Coll., which regulated the house tax (this was preceded by Act No. 80/1952 Coll. on house tax). The introduction of the agricultural tax was related to the post-war changes [Slovinský, Girášek 1974: 180]. One of its components was the land tax. It was based on the land area and rates, classified according to economic production groups in the rate book, which formed an annex to the Act. The house tax has been levied according to the built-up area of family

\footnotetext{
${ }^{4}$ Namely (Art. 24 of Act No. 317/1992 Coll.):

a) first part and provisions of Articles 23, 25, 26, 27, 28, 32, 33 and 41 of Act No. 172/1988 Coll. on agricultural tax, in so far as they regulate land taxes,

b) Act No. 143/1961 Coll. On house tax as amended by Act of the Slovak National Council No. 134/1974 Coll.,

c) Art. 6 of the Act of the Slovak National Council No. 544/1990 Coll. on local fees as amended by Act of the Slovak National Council No. 72/1992 Coll.,

d) Regulation of the Government of the Slovak Socialist Republic No. 83/1978 Coll. on the exemption of residential houses with flats in personal ownership from the House tax,

e) Ordinance of the Ministry of Finance No. 144/1961 Coll., which implements the House Tax Act,

f) Ordinance of the Ministry of Finance No. 14/1968 Coll. on house tax relief, as amended, as amended by the Ordinance of the Ministry of Finance of the Slovak Socialist Republic No. 143/1976 Coll. and Ordinance of the Ministry of Finance of the Slovak Republic No. 110/1991 Coll.,

g) Ordinance of the Ministry of Finance of the Slovak Socialist Republic No. 219/1988 Coll. on the payment of rent to special rent accounts, as amended by the Ordinance of the Ministry of Finance of the Slovak Republic No. 110/1991 Coll.,

h) Regulation of the Government of the Slovak Republic No. 48/1992 Coll. on tax relief for self employed farmers, and

i) Regulation of the Government of the Slovak Republic No. 65/1991 Coll. on house tax relief.
} 
houses used in full or partially by the owner or close persons to him/her, or according to the rent or price for use of buildings, in case of other buildings.

The House Tax Act replaced the previous regulation of the pre-war Act No. 76/1927 Coll., which established land tax and house tax (divided into tenement house tax for rented houses and class tax for other non-rented houses which include rooms for residing) and which replaced the previous Hungarian regulation ${ }^{5}$ based on the tax cadastres compiled between 1870 and 1890 [Podrimavský 1992: 114] accepted by Czechoslovakia after its establishment in 1918 by so-called reception standard ${ }^{6}$ (on the territory of Slovakia).

The current law and its regulation of real property tax have been frequently amended various changes have been introduced so far by as many as 30 Acts. Several of them had a significant role, or regulated important (authority) aspects of the real property tax legislation. We may consider as the most important those Acts that significantly modified the authority of municipalities to set tax rates ${ }^{7}$, while this trend is not unequivocally positively received by the academics [Bujňáková, Románová 2014: 67]. For example, M. Vernarský [2018: 265] evaluates the development of the legal regulation of the real property tax rates in Slovak conditions as a process in which the legislator has moved from partial improvements of the adequately balanced concept of determining tax rates to a gradual, but systematic reduction of the tax autonomy of municipalities. Other important changes to the Local Tax Act are amendments represented by Acts No. 517/2005 Coll., No. 538/2007 Coll., No. 460/2011 Coll., No. 347/2013 Coll., No. 268/2014 Coll. ${ }^{8}$, No.

\footnotetext{
${ }^{5}$ It was based on Act. Art. VII/1875 on the adjustment of land tax, Act Art. VI/1909 on house tax, Act Art. XXXII/1916 on property tax.

${ }^{6}$ Act of the National Committee of Czechoslovakia No. 11/1918 Coll. of 28 October 1918 on the establishment of an independent Czechoslovak state.

7 The first amendment by the Act No. 517/2005 Coll., amending Act No. 582/2004 Coll. on local taxes and local fee for municipal waste and small construction waste, as amended (the rate of land tax may not exceed 20 -fold base rate and in the case of tax on buildings and flats 40 -fold base rate the lowest annual rate determined in general binding regulation, in the case of tax on nonresidential premises 10-fold base rate); amended by the Act No. 527/2010 Coll. (for land tax, this limit was reduced from 20 -fold to 5 -fold base rate), by Act No. 460/2011 Coll. (a sanction has been introduced for non-compliance with the above limits by applying the statutory tax rate in such cases, and further reduction of the limits on tax rates on buildings and flats from 40 -fold to 10 fold base rate. The new rules were to be introduced by municipalities within the time limit. margins on the basis of newly introduced intertemporal provisions), by the Act No. 347/2013 Coll. (the transitional provisions were adjusted and the limit for harmonization of rates has been introduced, namely until 2024), by the Act No. 268/2014 Coll. (for the tax on arable land, hop-fields, vineyards, orchards, permanent grassland, forest lands on which there are commercial forests, fish ponds and other economically used water areas, a limit of the maximum amount of the tax rate of up to 5 times the statutory rate (0.25\%) has been introduced, i.e. max. $1.25 \%$ ), by the Act No. 333/2014 Coll. (5fold limit from the previous amendment has been increased to 10- fold the statutory rate for forest lands on which there are commercial forests, fish ponds and other economically used water areas).

8 The amendment sets out new categories of land and buildings, namely for land on which a transformer station or sales booth for the sale of goods and provision of services are located, the
} 
243/2017 Coll., No. 112/2018 Coll., as a result of which the definitions of particular terms, the scope of taxation, methods of classification of individual types of real property and the corresponding determination of the tax base and rates has been amended and refined, as well as the methods for establishing of individual parts of the municipality and the scope of tax exemptions and reductions applicable by municipalities, together with procedural aspects (for more on the amendments see [Kubincová 2020: 21-39]).

\section{Real property taxation in practice - the case of the City of Košice}

The effect of legislation (the impact of changes) in the field of real property taxation was analyzed by the authors at the local level, i.e. at the level of a specific municipality ${ }^{9}$, namely the City of Košice. From historical sources [Hajduová, Bartoš 2014; City of Košice; Eobce.sk; Ostrolucká 2013: 53-58; Halaga 1992] it can be read that the beginnings of settlement at the territory of the City of Košice dates back to the end of the Early Stone Age. The first written mention of the southern suburbs is from 1230. The oldest guild statutes in the country from 1307 have been preserved, and in 1369 Košice, as the first city in Europe, received its own coat of arms. From the beginning of the 15th century, Košice was part of the Pentapolitan (a union of five East Slovak cities), where it had a leading position. From 1347 until the beginning of the 18th century, Košice retained the position of the second city of Hungary after Buda. In the present, the City of Košice, with a population of 239,141 - data as of 31 December 2016 [City of Košice; Statistical Office of the Slovak Republic], is the second largest urban agglomeration in the Slovak Republic. As a separate legal entity, it is divided into 22 city districts (the issue of their consolidation was addressed by e.g. [Csachová 2016]). The statute, self-government and other legal aspects of the activities of the City of Košice are regulated by Act No. 401/1990 Coll. on the establishment of the City of Košice as amended. Besides to other basic aspects of city life,

law defined a special method of calculating the tax base and municipalities may set a special tax rate (as well as in the case of land for which a mining permit for an unreserved mineral has been issued, or on which there is a plant for the production of electricity from solar energy), whereas the annual rate of land tax set in this way must not exceeding 5 times the lowest land tax rate set by the tax administrator in the Generally Binding Regulation, and further subdivided the construction of garages into free-standing garages, the construction of collective garages and the construction of underground collective garages, which allows municipalities to diversify tax rates for these buildings. ${ }^{8}$ For more on the amendments see [Kubincová 2020: 21-39].

${ }_{9}^{9}$ Pursuant to Art. 64 of the Constitutional Act No. 460/1992 Coll. the Constitution of the Slovak Republic, the municipality is the basis of territorial self-government. Pursuant to Act No. 369/1990 Coll. on municipalities, as amended, the municipality performs functions within the delegated performance of state administration or within self-government. Pursuant to Art. 4 (3) of the Act, within the exercise of self-government, the municipality also decides on matters of local taxes and administers them. A municipality may be declared a city if it meets the criteria set out in the Art. 22 of this Act. 
in the Art 10 (3) of the Act the city council is entrusted with the exclusive authority to decide on the introduction and abolition of local taxes and to determine their requirements. The city may, by its statute, transfer the performance of certain selfgoverning powers based on special regulations, to all city districts or only to certain city districts, as the principles of self-government powers sharing between the city and city districts $^{10}$ are determined by the Art. 18 (c) of the city statute. In Košice, however, the exercise of authority regarding the real property tax has not been delegated to the districts and has remained within the authority of the city since 2005, when the City of Košice became the administrator of real property tax instead of its districts [Petrániková 2018: 188].

\subsection{The development of local RPT regulation in Košice}

The first GBR of the City of Košice, which introduced a real property tax under the new law, was the General Binding Regulation of the City of Košice No. 71 on local taxes approved by the resolution of the Municipal Council in Košice No. 1237/2006 of 7 December 2004. It included not only real property tax adjustments, but also local taxes on dogs, vending machines and non-winning gaming machines. For the purposes of differentiation in tax rates - zoning of the city territory in accordance with Art 17 (6) of the Local Tax Act, two individual parts of the municipality were selected as categories, namely Category I and Category II ${ }^{11}$. The GBR defined, pursuant to the statutory mandate, rates for taxes on land, buildings and flats and non-residential premises, floor surcharge, tax reductions and exemptions. This regulation was amended six times, already on 16 December 2004 - by the resolution of the Municipal Council in Košice No. 635/2004 (there was an adjustment of exemptions from tax on land and buildings), by the resolution of the Municipal Council in Košice No. 931/2005 of 15 December 2005 (the categories individual parts of the city were adjusted, building tax rates, tax reductions and exemptions and the method of tax payment were amended, including the determination of tax

\footnotetext{
10 Pursuant to the Art. 2 (2), the city is divided into following city districts: Kavečany, Ťahanovce, Sever, Staré Mesto, Lorinčík, Pereš, Myslava, Zípad, Dargovských hrdinov, Košická Nová Ves, Barca, Šebastovce, Krásna, Nad jazerom, Juh, Šaca, Pol’ov, Sídlisko Tahanovce, Sídlisko KVP, Džungla, Vyšné Opátske, Luník IX.

${ }^{11}$ The Category I consists of cadastral areas: Čermel', Stredné mesto, Huštáky, Letná, Severné mesto, Kamenné, Brody, Nové Ťahanovce, Terasa, Grunt, Železiarne, Furča, Južné mesto, Skladná, Jazero; II. the category consisted of cadastral areas: Ťahanovce, Kavečany, Luník, Myslava, Lorinčík, Pereš, Pol'ov, Šaca, Košická Nová Ves, Vyšné Opatské, Nižná Úvrat', Krásna, Barca pri Košiciach, Šebastovce [Art. 2 par. 2 GBR No. 71 in its original wording].
} 
payment in instalments ${ }^{12}$ ), by the resolution of the Municipal Council in Košice No. $1237 / 2006$ of 14 November 2006 (again the categorization was changed ${ }^{13}$ and changes in tax reductions and exemptions were introduced), by the resolution of the Municipal Council in Košice No. 360/2007 of 14 December 2007 (the number of categories has been increased from two to three ${ }^{14}$, as a result of which there was a comprehensive change in tax rates, rewording of the text and minor adjustments in the categories of buildings and adjustment in exemptions and tax reductions), by the resolution of the Municipal Council in Košice No. 624/2008 of 31 October 2008 (but only related to the dog tax), and the resolution of the Municipal Council in Košice No. 671/2008 of 10 December 2008 (adjusted tax rates on buildings and flats due to the introduction of the Euro currency, including minor adjustments to tax reductions).

With effect from 1 January 2013, this regulation was replaced by a new Generally Binding Regulation of the City of Košice No. 132 on local taxes, which was adopted by the resolution No. 443/2012 of 10 December 2012 of the Municipal Council in Košice. The new regulation imposed the same types of local taxes as the previous one, and maintained the categorization of individual parts of the city as well. So far, it has been changed three times, by the resolution of the Municipal Council in Košice No. 803/2013 of 16 December 2013 (amended changes in tax reductions), the resolution of the Municipal Council in Košice No. 5/2014 of 8 December 2014 (establishing changes in relation to the amendments to the Local Tax Act by the amendment by the Act No. 268/2014 Coll., which established new categories of land and buildings; it also involved changes in tax reductions) and by the resolution of the Municipal Council in Košice No. 325/2019 of 13 December 2019.

The development in the tax burden due to changes in tax rates is documented in the attached Graphs No. 1 to 3. From the overall view on the development in individual rates, it is possible to conclude a long-term trend of a higher tax burden on real property located in the city centre, compared to its peripheral parts, which corresponds to the standard

\footnotetext{
12 Parts of the cadastral area of Južné mesto, namely Hraničná, Barčianska, Gavlovičova and Vozárova streets, were detached from the Category I area and moved to the Category II area.

${ }^{13}$ The cadastral area of Kamenné was detached from the area of the Category I., and moved to the Category II area.

${ }^{14} \mathrm{~A}$ new Category I was created, where only the cadastral area of Stredné mesto was included, the other areas of the original Category I form the Category II (Huštáky, Letná, Skladná Čermel', Severné mesto, Brody, Nové Ťahanovce, Terasa, Grunt, Železiarne, Furča, Južné mesto, except for the streets Hraničná, Barčianska, Gavlovičova, Vozárova, Jazero) and the Category III consists of the areas of the original Category II (Ťahanovce, Kavečany, Luník, Myslava, Lorinčík, Pereš, Polov, Šaca, Košická Nová Ves, Vyšné Opatské, Nižná Úvrat', Krásna, Barca, including Hraničná, Barčianska, Gavlovičova a Vozárova, Šebastovce, Kamenné streets).
} 
principles of applying tax policy in the field of real property tax. The year 2020 can be clearly identified as the year in which the highest year-to-year increase in average real property tax rates occurred (by $79.84 \%{ }^{15}$ ), what in practice could motivate taxpayers to look for ways to avoid paying tax or pay it at a lower rate (for example, due to a different assessment of the purpose of the buildings used e.g. in the airbnb accommodation offer ${ }^{16}$, which is part of the emerging trend of a shared economy development in the 21st century [Bonk 2019; Hučková, Bonk, Rózenfeldová 2018].

Graph No. 1/A, 1/B: The development of average tax rates for tax on lands.

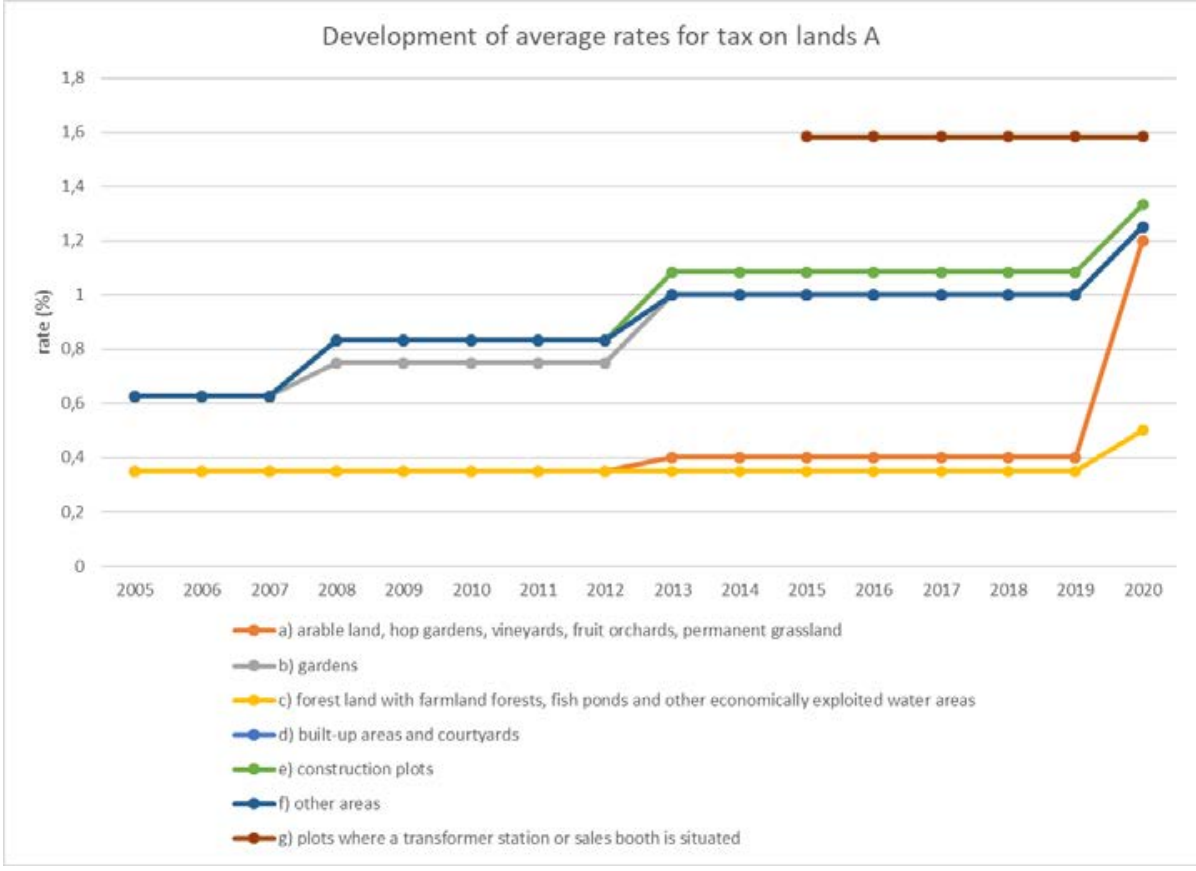

15 In 2013, average rates had been increased by $22.38 \%$ and in 2008 by $7.89 \%$.

${ }^{16}$ Airbnb, Inc. is an American vacation rental online marketplace company, which through the web service arranges the rental of accommodation provided by individuals (citizens) who rent a vacant room in their property, or the renting of the whole apartment, house. 


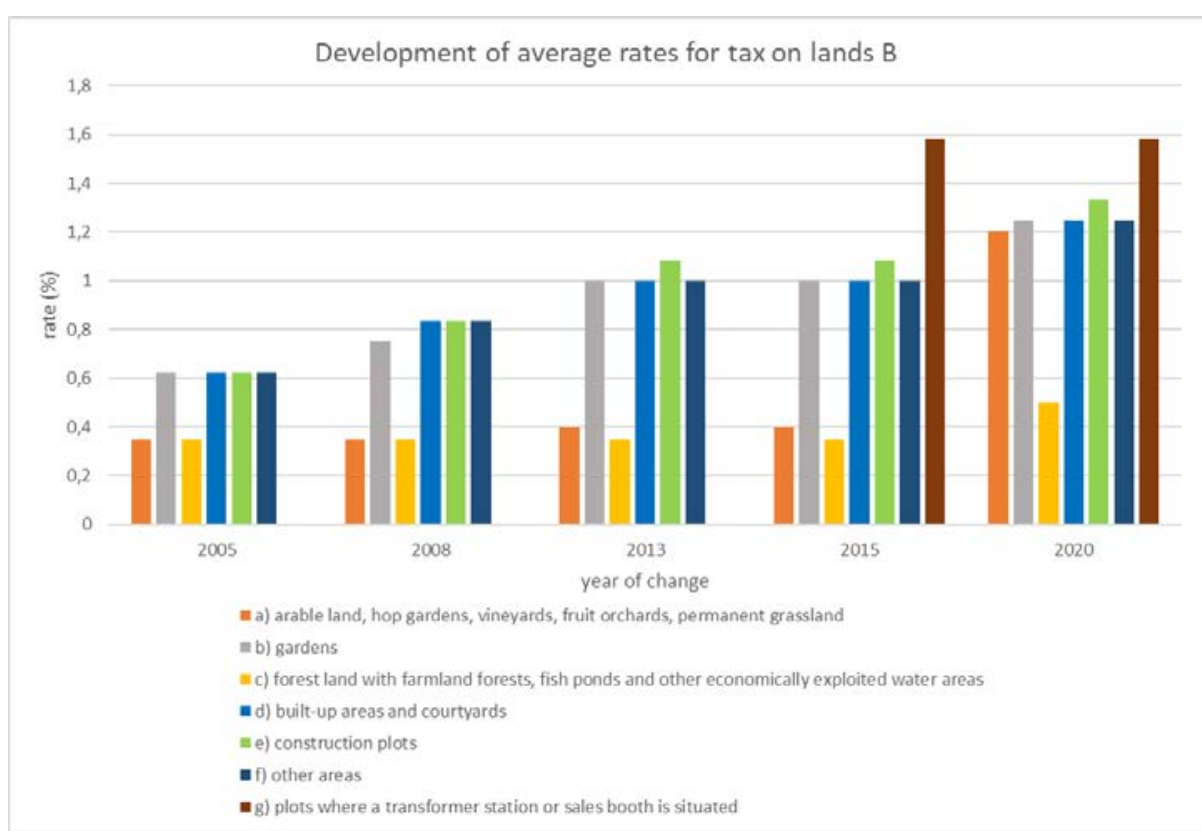

Source: Author's own elaboration based on data published in the generally binding regulations regulating the local taxes at the web page of City of Košice (https://www.kosice.sk/vzn).

In the development of land tax rates, we identify a more significant increase in average rates with effect from 2008 (by 23.44\%), 2013 (by 22.36\%), 2015 (by 13.8\%) and especially from 2020 (by 30,39\%), where the increase was the most significant. In addition, since 2015, the highest of all tax rates among individual types of land has been applied to a land on which transformer stations or sales booths are located. 
Graph 2/A, 2/B: The Development of average tax rates for tax on buildings
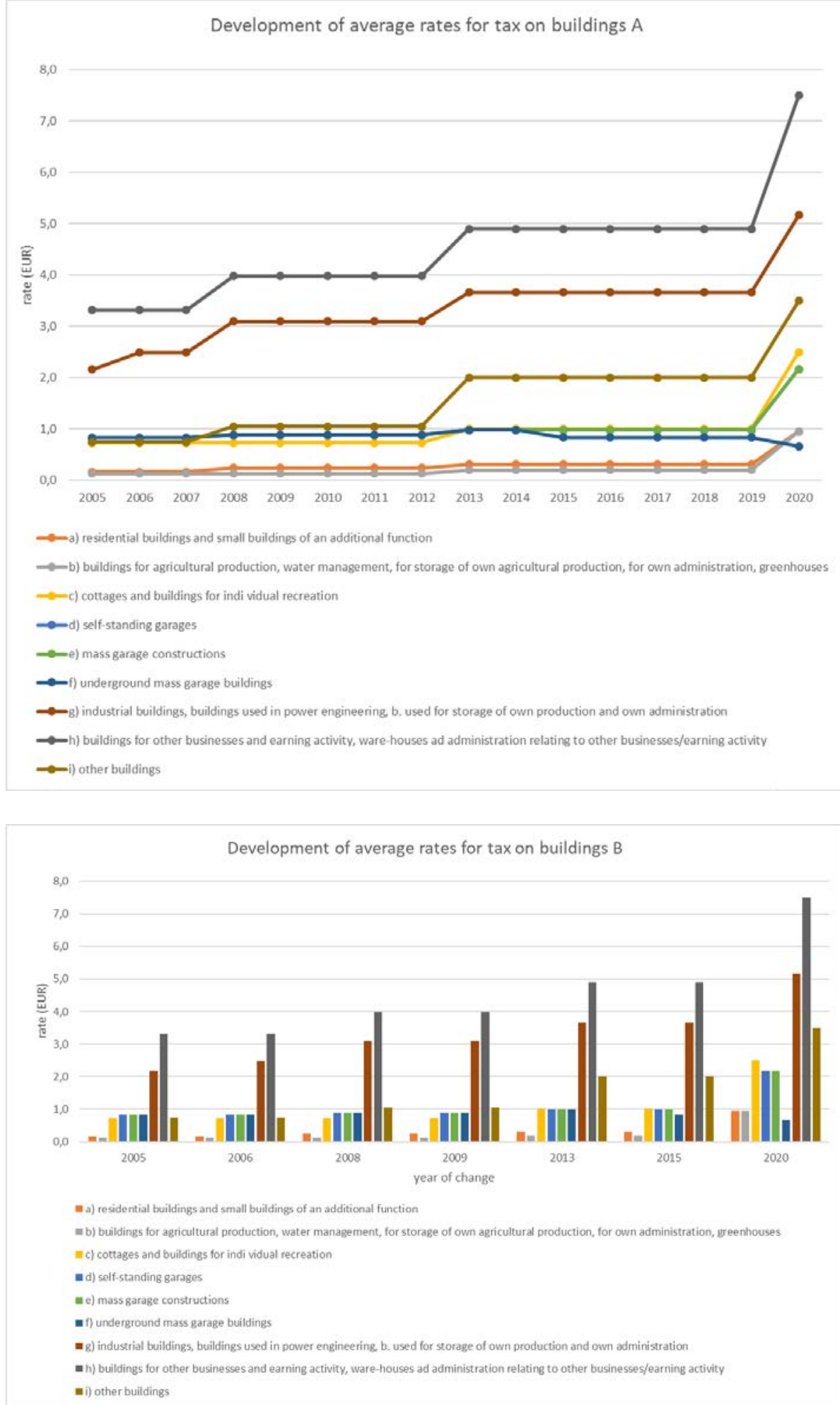

Source: own processing based on data published in the generally binding regulations regulating the local taxes at the web page of City of Košice (https://www.kosice.sk/vzn).

Similarly to the land tax, the most significant increase in average buildings tax rates occurred with effect from 2008 (by 18.06\%), 2013 (by 26.33\%), and especially from 2020 
(by $71.85 \%$ ), but for buildings of underground collective garages the tax rate decreased in 2015 (by 15.25\%) and in 2020 (after rounding by 20\%), which shows a clear trend to support efforts to place garages in underground spaces.

\section{Graph 3/A, 3/B. The Development of average tax rates for tax on flats and non-residential permises}
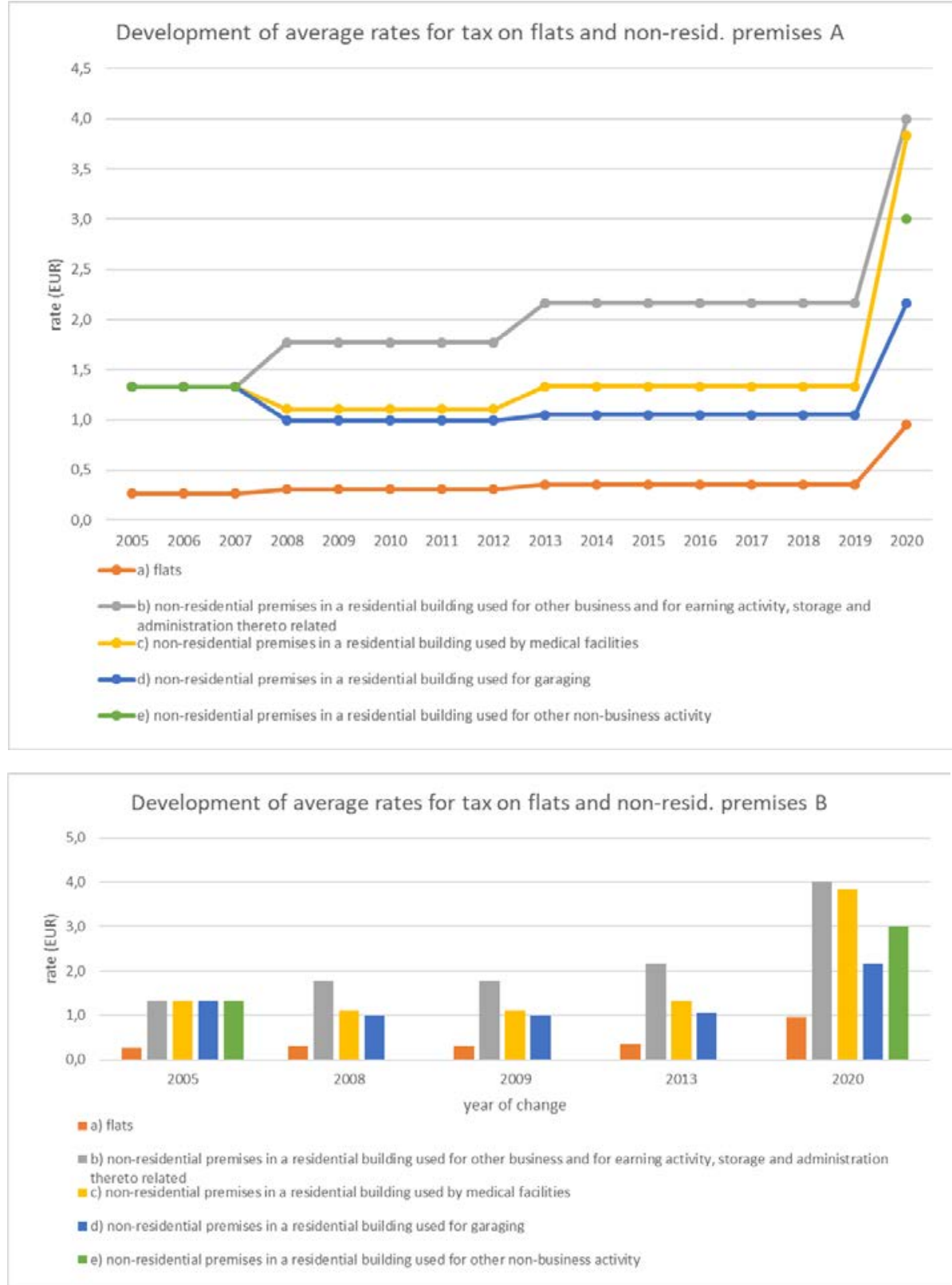

Source: Author's own elaboration based on data published in the generally binding regulations regulating the local taxes at the web page of City of Košice (https://www.kosice.sk/vzn).

In the case of flats tax rates, there was the most significant year-to-year increase in 2020 (by $168.46 \%$ on average), (in 2013 there was an increase of only $14.45 \%$ and in 2008 by $16.64 \%$ ), in contrast to the rates for non-residential premises tax, where the development 
was more diverse. In 2008 , due to the separation of rates for different types of nonresidential premises, their average rate decreased (albeit by less than 3 percent), due to a decrease in average rates for premises used as medical facilities (by 16.66\%) and garages (by $25 \%$ ) and the increase in rates for premises for other business activities, storage and related administration (by 33.33\%). On the other hand, average rates increased in 2013 (by $17.56 \%$ ) and in 2020 (by 114.28\%). In 2020, a special rate was introduced for nonresidential premises used for other non-business activities, which had not been taken into account before. Until 2008, non-residential premises were taxed at a single rate as one general Category of non-residential premises and their rates were not diversified in more detail. In total, the average tax rate on flats and non-residential premises increased by $127.57 \%$ in 2020.

\subsection{The development of RPT revenues in Košice}

Within the second stage of the research, we have analyzed the available and provided data on total revenue, tax revenue and revenue from real property tax within the period from 2005 to 2019 for the City of Košice, which are presented in the following Graphs No. 4 and 5 and in the text part of this subchapter.

Graph No. 4: Development of revenues of City of Košice

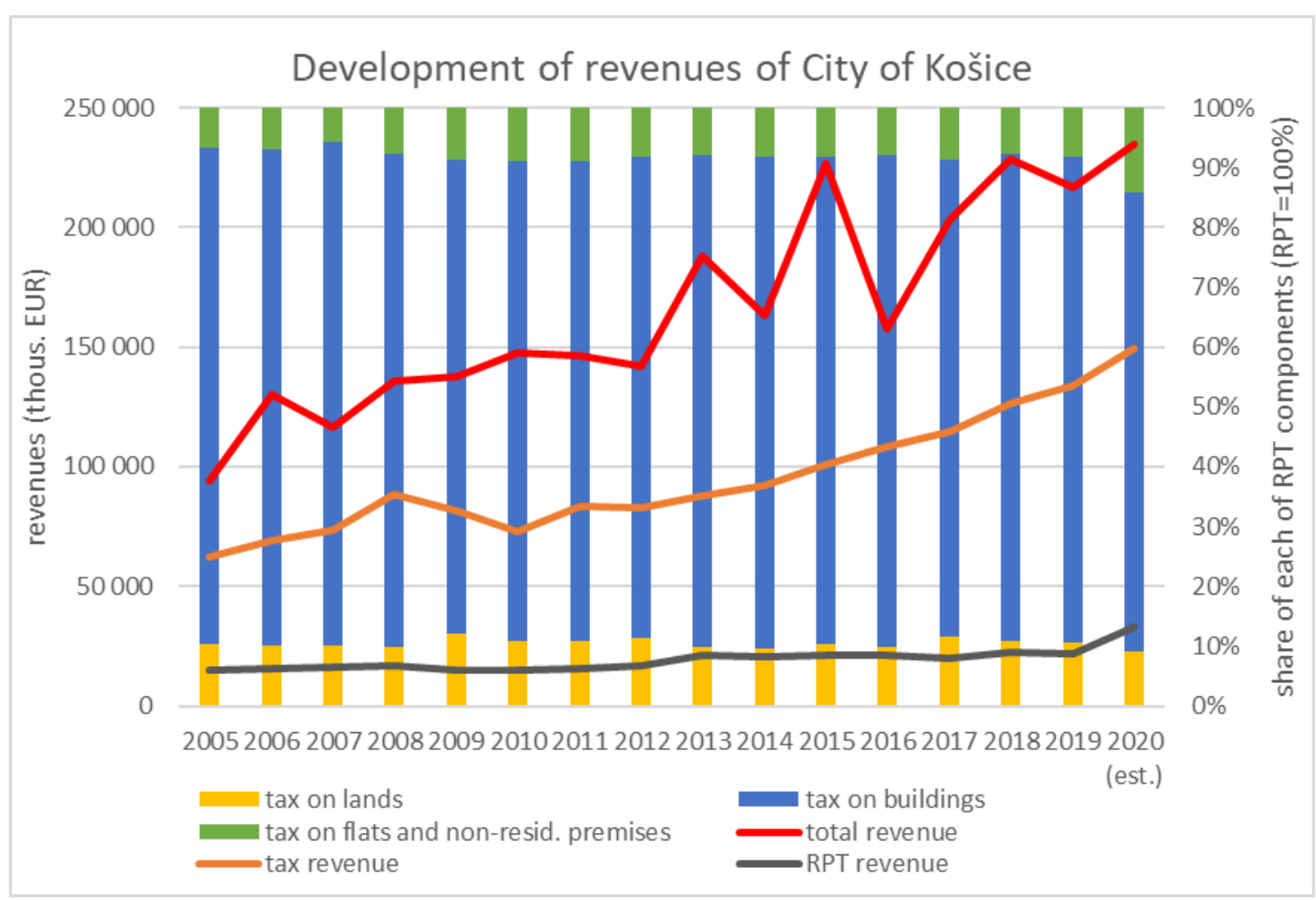

Source: Author's own elaboration based on data provided by the City of Košice. 
Development in total revenues for the City of Košice during the years 2004-2020:

- $\quad$ the year-to-year development in total revenue from 2004 (in absolute value of EUR 111,684,359) to 2019 (in absolute value of EUR 216,802,249) had a tendency to fluctuate: the year-to-year decrease in revenue in this period ranged from $0.51 \%$ in 2011 to $69.38 \%$ in 2016 and an increase was within the range of $1.66 \%$ in 2009 to $39 \%$ in 2015 ;

- $\quad$ the highest total revenue (EUR 228,789,237) in the observed period has been reported by the City of Košice in 2018 and the lowest revenue (EUR 93,933,546) in 2005;

- $\quad$ the most significant year-to-year change was reported in 2015, namely a yearto-year increase in total revenue by $39 \%$ and also in 2006 when there was an increase by $38.85 \%$; the most significant year-to-year decrease in total revenue was reported in 2016 (by 69.38 percentage points);

- $\quad$ the currently adjusted planned amount of total revenue for 2020 is in absolute value EUR $234,697,069$, which represents an increase by $8.25 \%$, compared to 2019.

\section{Development in tax revenues for the City of Košice in the period 2004-2020:}

A year-to-year development in tax revenues of the City of Košice for the period from 2004 (EUR 24,184,193) to 2019 (EUR 133,888,972) had, except for 2009 (when there was a decrease by 7.68\%), 2010 (decrease by 10.96\%) and 2012 (a decrease by $0.95 \%$ ) a permanently growing trend within the range from $5.09 \%$ (in 2014) to $157.1 \%$ (in 2005);

the highest absolute value of tax revenues (EUR 133,888,972) has been reported by the City of Košice in 2019 and the lowest absolute value (EUR 24,184,193) in 2004;

the highest year-to-year increase in tax revenues of the City of Košice within the observed period was reported in 2005 , namely by $157.1 \%$ and the most significant year-to-year decrease was reported in 2010 (by $10.96 \%$ );

the planned tax revenue for 2020 in the absolute value is EUR 149,277,873, which represents a year-to-year increase by 11.49 percentage points. 
Graph No. 5: Development of RPT revenues

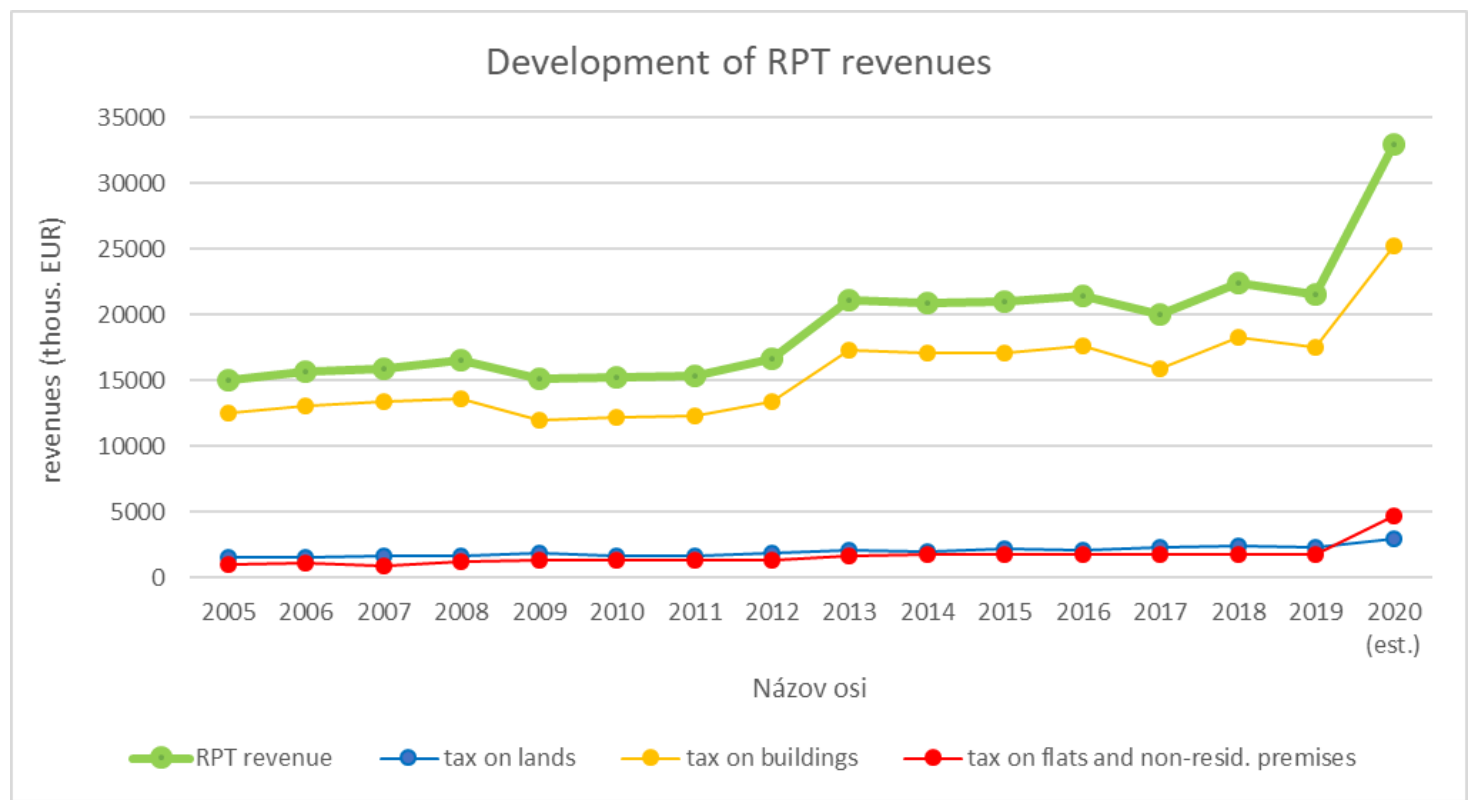

Source: Author's own elaboration based on data provided by the City of Košice

\section{Development in revenues from real property tax:}

- $\quad$ The year-to-year development in revenues from real property tax within period from 2005 (EUR 15,085,043) to 2019 (EUR 21,592,462) ranged within the interval of increase by $0.8 \%$ to $26.58 \%$ to the interval of decrease by $0.96 \%$ to $8.76 \%$ in the year-to-year property tax revenue;

- $\quad$ the highest absolute value of revenue from real property tax (EUR 22,482,730) has been reported by the City of Košice in 2018 and the lowest value (EUR $15,085,043)$ in 2004;

- $\quad$ the highest year-to-year increase in revenue from real property taxes within the observed period has been reported in 2013 - by $26.58 \%$ and the most significant year-to-year decrease by $8.76 \%$ has been reported in 2009 ;

- $\quad$ for 2020 the revenue from real property tax in an absolute value of EUR $33,000,000$ is planned, what represents a year-to-year increase by 52.83 percentage points.

\section{Development in revenues from land tax:}

- $\quad$ The year-to-year development in revenues from land tax for the period from 2005 (EUR 1,569,807) to 2019 (EUR 2,302,605) ranged within the interval of increase by $0.26 \%$ to $13.2 \%$ to the interval of decrease by $3.8 \%$ to $6.39 \%$ in the year-to-year land tax revenues; 
- $\quad$ the highest absolute value (EUR 2,459,655) of revenue from land tax has been reported by the City of Košice in 2018 and the lowest absolute value (EUR $1,569,807)$ in 2005 ;

- $\quad$ the highest year-to-year percentage increase in land tax revenue within the observed period has been reported in 2012 (by 13.2\%) and the most significant year-on-year decrease was reported in 2016 (by 6.39\%);

- $\quad$ for 2020, the revenue from land tax in an absolute value of EUR 3,000,000 is planned, which represents a year-to-year increase by 30.29 percentage points.

\section{Development in revenues from tax on buildings:}

- Development in revenues from tax on buildings in absolute values for the period from 2005 (EUR 12,512,116) to 2019 (EUR 17,536,898) ranged within the interval of increase by $1.12 \%$ to $29.07 \%$ to the interval of decrease by $0.22 \%$ to $12.39 \%$ in the year-to-year buildings tax revenue;

- $\quad$ the highest absolute value (EUR 18,265,262) of revenue from the tax has been reported by the City of Košice in 2018 and the lowest absolute value (EUR $11,950,998$ ) in 2009;

- $\quad$ the highest year-to-year percentage increase by $29.07 \%$ from the buildings tax within the observed period has been reported in 2013 and the most significant year-to-year decrease (by 12.39\%) has been reported in 2009;

- $\quad$ for 2020, the revenue from tax on buildings in the amount of EUR 25,300,000 is planned, which represents a year-to-year increase by 44.27 percentage points.

\section{Development in revenue from tax on flats and non-residential premises:}

- Development in revenues from tax on flats and non-residential premises ranged, in the period from 2005 (EUR 1,003,120) to 2019 (EUR 1,752,959), within the interval of the year-to-year increase by $0.36 \%$ to $36.17 \%$ and within the interval of year-to-year decrease by $0.2 \%$ to $14.29 \%$;

- $\quad$ the highest absolute value (EUR 1,757,813) of the revenue from tax on flats and non-residential premises has been reported by the City of Košice in 2018 and the lowest absolute value (EUR 925,812) in 2009;

- $\quad$ the highest year-to-year percentage increase in the revenue from tax on flats and non-residential premises has been reported in 2008 (by 36.17\%) and the most significant year-on-year decrease was reported in 2007 (by 14.29\%); 
- $\quad$ for 2020, the revenue from tax on flats and non-residential premises is planned in the amount of EUR 4,700,000, which represents a year-to-year increase by 168.12 percentage points.

\section{Discussion}

By applying standard scientific methods (analysis, deduction, abstraction, comparison), we have examined and evaluated the impact of changes in legislation [Local Tax Act, General Binding Regulations of the City of Košice No. 71 and No. 132 on local taxes, as amended] on the development of revenues from real property tax at a specific entity (the City of Košice) within the period from 2004/2005 to 2019, and with predictions for 2020. Within the course of research, various primary and secondary data and information has been used from sources indicated in the list that is part of this paper.

The total revenue of the City of Košice had a fluctuating development during the period from 2004 to 2016 (see Graph No. 4), where a year-to-year increase has been reported (the most significant in 2015), but also a year-to-year decrease (the most significant in 2016); for 2020, there is currently planned value of the total revenue for the City of Košice in the amount of EUR 234,697,069 (adjusted as of March 31, 2020), which represents a $6.88 \%$ increase, compared to 2019. In connection with the epidemiological situation during 2020 , it can be expected that the achievement of the planned budget revenue will be negatively affected by this situation (for example, a decrease in revenue from shared taxes).

The tax revenues of the City of Košice within the period 2004-2019 had a growing yearto-year trend (the most in 2005 by $157.1 \%$, when municipalities were first authorized to introduce their own tax rates under the new Local Tax Act), except for 2009, 2010, 2012 when there was a decrease (the most significant in 2010 by $10.96 \%$ ); for 2020, the planned tax revenues of the City of Košice in the absolute value amount to EUR $149,277,873$, which represents a year-to-year increase of $11.49 \%$ (compared to 2019).

Revenue from taxation of real property (from land, buildings, flats and non-residential premises) within in the period 2005-2019 showed a growing year-to-year trend, except for decrease in revenues in 2009 (by 8.76\%), 2014 (by 1.34\%), 2017 (by 6.73\%) and 2019 (by $0.96 \%$ ). The most significant year-to-year increase in revenue occurred in 2013 (by 26.58\%), when the City of Košice through the new GBR No. 132 on local taxes rates had increased individual taxes (by $22.36 \%$ for land, $26.33 \%$ for buildings and for flats and nonresidential premises by $17.33 \%$ ). The most significant year-to-year decrease has been 
reported in 2009, where no changes in rates or other significant changes had been introduced by the GBR, apart from the below-mentioned adjustments to the tax reduction in the selected cases.

Revenue from land taxation within the period 2005 to 2019 showed an increasing year-toyear trend, except for a decrease in 2010 (by 9.78\%), 2014 (by 4.6\%), 2016 (by $3.8 \%$ ) and 2019 (by 6.39 \%). The highest year-to-year increase in revenue within the observed period (by $13.2 \%$ ) was reported in 2012. With effect from 2015, a special category of land (on which a transformer station or a sales booth is located) was introduced by the Local Tax Act, where the city also sets a special (highest applied) tax rate and also changes to the Local Tax Act after amendment by the Act No. 268/2014 Coll. have been introduced. In terms of revenue, there was a slight year-to-year increase in revenue from land taxation in that year (by $8.52 \%$ ). There were no changes to the GBR affecting 2010 or 2012, so we did not find a direct connection with the examined legislation.

Revenue from buildings taxation within the period 2005 to 2019 showed an increasing year-to-year trend, except for a decrease in 2009 (by 12.39\%), 2014 (by 1.19\%), 2015 (by 0.22\%), 2017 (by 9.5\%) and 2019 (by 3.99\%). The highest year-to-year increase in revenue from buildings tax in the observed period was reported in 2013 , namely by $29.07 \%$. From this year, the new GBR No. 132 came to effect, which introduced a rate increase (on average by $26.33 \%$ ), with the increase affecting all types of buildings, further increasing the floor surcharge (to a uniform EUR 0.16 for all categories); the scope of the exemptions and reductions remained at a similar extent as in the previous arrangements. The most significant year-to-year percentage decrease was reported in 2009 , namely by $12.39 \%$. In that year, however, there was no adjustment of tax rates (only conversion to the euro currency) and the amendment to the GBR of 10 December 2008 contains only minor adjustments to the reduction of buildings tax (a reduction by $50 \%$ in two cases ${ }^{17}$ ). In 2007 , floor surcharges were introduced (in the amount of SKK 5/EUR 0.166 for Category I and SKK 3/EUR 0.1 for the Category II), but there was no significant increase in tax revenues (year-to-year increase by $2.09 \%$ ).

Revenue from taxation of flats and non-residential premises within the period 2005 to 2019 showed an increasing year-to-year trend, except for a decrease in 2007 (by 14.29\%), 2011 (by $0.2 \%), 2016$ (by 0.49\%) and 2019 (by 0.28\%). The highest year-to-year increase in revenue from taxation of flats and non-residential premises in the observed period was

\footnotetext{
17 It covers buildings or houses located on undermined land or on land endangered by landslides, museums, galleries, libraries, theaters, cinemas, amphitheatres, exhibition halls and educational facilities. Point 5 of the amendment to the Art. 11 par. 5 of the GBR No. 71.
} 
reported in 2008 (by 36.17\%). Although average year-to-year rates decreased in that year, the diversification of tax rates for different cases of non-residential premises use came into effect (which were previously taxed at a single rate), although there was a decrease in average rates for premises used as medical facilities (by 16.66\%) and garages (by 25\%), but also an increase in rates for premises used for other business activities, storage and related administration (by 33.33\%). There has been an increase in tax rates for the apartments. The amendment to the GBR of 14 December 2007 changed the categorization of individual parts of the city for the purpose of setting rates (expansion from two to three categories, as a result of which the tax burden on individual flats and non-residential premises changed depending on their location. Real properties of the Category I were rearranged into the new Category I, where average rates rose, and Category II, where they fell. The properties from the original Category II were moved to Category III and the average rates fell compared to their previous classification. The highest year-to-year decrease in tax rates has been reported in 2007 (by 14.29 \%) when, however, tax rates did not change. In addition, the amendment to the GBR of 14 November 2006 did not contain any fundamental changes, but contained a slight extension of the scope of the tax reduction ${ }^{18}$.

\section{Conclusions}

The revenues from real property tax accounted for $16.13 \%$ to $24.26 \%$ of the reported tax revenues of the City of Košice in the period 2005 - 2019. Permanently, the highest share of revenue from real property taxation was the revenue from buildings tax $(81.22 \%$ to 84.01\%), for 2020 the planned share is at the level of $76.66 \%$. With regard to this fact we conclude that the most significant impact on changes in total revenue from real property tax are represented by changes in the legislation (national/local) in the area of taxation of buildings. The other two components of real property taxation represent a comparable share, namely revenue from the land tax and from the tax on flats and non-residential premises, a slightly more significant share is represented by the revenue from land tax, while for 2020 this position of revenue from the land tax versus the revenue from taxation of flats and non-residential premises should be changed (the revenue from land taxation up

\footnotetext{
${ }^{18}$ For more see point 5 of the amendment amending the Art. 11 par. 3 of the GBR No. 71, by which the reduction of tax by $30 \%$ is set for: (a) buildings or housing serving for rehabilitation and the retraining of people with reduced working capacity, buildings used for social assistance and for museums, galleries, libraries, theaters, cinemas, amphitheatres, exhibition halls and educational premises; (b) buildings or housings the use of which is restricted due to extensive restoration or building closures, (c) residential buildings, other buildings forming part of the main building and flats owned by citizens in material need and citizens over the age of 70, which are used for their permanent housing.
} 
by $9.1 \%$ and the revenue from taxation of flats and non-residential premises up by 14.24 $\%)$. We have identified a causal relation between the change in the amount of revenue from individual components of real property tax and the change in its legislation, primarily caused by changes in the tax rates, which fact was not confirmed in each individual case of the year-to-year changes in the value of revenue from taxation by individual components of the real property tax, where in some cases we identified a year-to-year change in revenue, namely in the years of the legislation change, but we cannot rule out the impact of other factors that affected the resulting reported numerical values of the property tax revenue - such as non-compliance with tax obligations (payment of $\operatorname{tax}^{19}$ ).

The planned revenue of the City of Košice from real property taxation for the year 2020 in the current absolute value of EUR 33,000,000 (which represents a year-to-year increase by $52.83 \%$ ), where the expected highest year-to-year value of increase in the revenue within the individual components of real property tax is for the tax on flats and nonresidential premises (namely by $168.12 \%$ ), for the tax on buildings (by $44.27 \%$ ), and for the tax on land (by $30.29 \%$ ) - in our opinion, the amount of planned revenues is conditioned by an amendment to the tax rates set by the City of Košice in the GBR, as there have been a significant increases in individual tax rates (for lands by an average of $30.39 \%$, for buildings by $71.85 \%$, and for flats and non-residential premises by $127.57 \%$ ).

\section{References}

Bolfíková, E.: Teória správy a byrokracie [Theory of administration and bureaucracy], Prešov: University of Prešov, 2017.

Balážová, E., Papcunová, V., Tej, J.: The Impact of the Fiscal Decentralization on the tax Revenue of real Estate tax on the Local Self-Government of the Slovak Republic, (in:) Klimova, V., Zitek, V (eds.) 19th International Colloquium on Regional Sciences. Brno: Masaryk University, 2016, pp. 891-898. DOI: 10.5817/CZ.MUNI.P210-8273-2016-115.

Bobáková, V.: Economy of the Local Authorities in the Slovak Republic, Warmińsko-Mazurski Kwartalnik Naukowy, nr 2 [18], pp. 35-52.

Bobáková, V., Rožová, L.: The income base of district towns in the Slovak republic, (in:) Public Administration Issue, nr 2 [5], 2019, pp. 121-134. DOI 10.17323/1999-5431-2019-0-6-121134.

Bonk, F.: Zdaňovanie ubytovacích služieb $v$ zdielanej ekonomike (príklad daňovej regulácie internetovej platformy Airbnb) [Taxation of accommodation services in a shared economy (example of tax regulation of the Airbnb internet platform)]. (in:) Dny práva 2018 (Days of Law 2018), Brno: Masaryk university, 2019, pp. 60-71.

Available at: http://www.daysoflaw.com/dokumenty/48928.

Bryson, P. J., Cornia, G. C., Wheeler, G. E.: Fiscal decentralization in the Czech and Slovak Republics: a comparative study of moral hazard. Environment and Planning C-Government and Policy. Environment and Planning C: Government and Policy 24, nr 1 [22], February 2004, pp. 13113.

19 Within the period from 2005 to 2019, the City of Košice has recorded tax arrears on real property tax in the total amount of EUR 2,208,234.82 (the highest in 2019, namely EUR 652,360.65 and the lowest in 2007, namely EUR 3,114.93) [data provided by the City of Košice]. 
Bujňáková, M., Románová, A.: Zamyslenie sa nad ideou zavedenia zdaňovania nehnutel'ností na princípe trhovej hodnoty [Thoughts about the idea to introduce the real market price based taxation of real property], (in:) Právo, obchod, ekonomika IV: zborník vedeckých prác (Law, commerce, economics IV: proceedings of scientific papers) Košice: Pavol Jozef Šafárik University in Košice, 2014. pp. 61-75.

Csachová, S.: Konsolidácia mestských častí v meste Košice - teoretické východiská a postoje verejných aktérov [Consolidation of city districts in the city of Košice - theoretical starting points and attitudes of public actors], Acta Politologica nr 1 [8], 2016, pp. 69-85.

Etel, L.: How to Reduce Costs of Local Tax Collection. Financial Law Review, 2019, vol. 15, issue 3 , pp. 75-85. DOI 10.4467/22996834FLR.19.015.11271.

Hajduová, M., Bartoš, M. (eds.): Košice v súradniciach európskych dejín [Košice in the coordinates of European history], Košice: Mesto Košice - archív mesta Košice [City of Košice - archive of the city of Košice], 2014.

Available at: https://static.kosice.sk/s/5259608c14854e2e719d6.

Halaga, O. R.: Počiatky Košíc a zrod metropoly [The beginnings of Košice and the birth of the metropolis], Košice: Východoslovenské vydavatel'stvo pre mesto [East Slovak publishing house for the city of Košice], 1992.

Hučková, R., Bonk, F., Rózenfeldová, L.: Zdiel'ané hospodárstvo - otvorené problémy a diskusia (najmä s prihliadnutím na obchodnoprávne a daňovoprávne súvislosti) [Shared economy open issues and debate (especially taking into account the commercial and tax context)], Studia luridica Cassoviensia, nr 2 [6], 2018, pp. 125-140.

Available at: http://sic.pravo.upjs.sk/files/12 huckova kolaborativna ekonomika revizia.pdf.

Juchniewicz, E.: The principle of fiscal local autonomy in the light of Polish Constitution, Financial Law Review, nr 2 [2], 2017, pp. 33-43. DOI 10.4467/22996834FLR.17.006.9034

Králik. A.: The Analysis of Municipalities' Revenues of Košice and Prešov, (in:) CERS 2014: 5th Central European Conference in Regional Science, International Conference Proceedings. Košice: Technical University in Košice, Faculty of Ecomnomics. 2015. pp. 471-478.

Kubincová, S.: Selected theoretical and application issues of local taxes, (in:) Tuláček, J. (ed.) Aktuálne otázky územnej samosprávy v podmienkach Slovenskej republiky [Current issues of local self-government in the conditions of Slovak republic]. Praha: Leges, 2020. pp. 5-53.

Maličká, L.: Formálna dimenzia fiškálnej decentralizácie v kontexte vertikálnej fiškálnej nerovnováhy a finančnej autonómie miestnych samospráv Slovenskej republiky [Formal dimension of fiscal decentralization in the context of vertical fiscal imbalance and financial autonomy of municipalities in Slovak Republic], In: Politická ekonomie [Political Economy], nr 3 [67], 2019, pp. 273-290. DOI 10.18267/j.polek.1240.

Maličká, L.: Principal Changes in the Structure of Municipal Revenues in the Period of 2000-2017 with an Emphasis on Fiscal Decentralization in Slovakia, Socioekonomické a humanitní studie [Socio-Economic Sciences and Humanities], nr 1 [9], 2019, pp. 45-63.

Nižňanský, V., Cibáková, V., Hamalová, M.: Tretia etapa decentralizácie verejnej správy na Slovensku. [Third phase of public adminnistration decentralisation in Slovakia], Bratislava: Wolters Kluwer, s. r. o., 2014.

Ostrolucká, M.: Správa mestského hospodárstva v Košiciach v 16. a 17. storočí [Administration of the Municipal Economy in Košice in the 16th and 17th Centuries], Mesto a dejiny [City and History], nr 1 [2], 2013, pp. 53-58.

Available at: https://www.upjs.sk/public/media/15021/MaD-2013-1-Ostrolucka.pdf.

Papcunová V., Nováková B.: Real Estate Tax as Part of Municipal Tax Incomes (case study) (in:) Vaňková I. (ed.) Public Economics and Administration 2019: 13th International Scientific Conference, Ostrava: Vysoká škola báňská - Technická univerzita Ostrava, 2019, pp. 22-22.

Petrániková, S.: Finančné riadenie územne členeného štatutárneho mesta [na príklade mesta Košice] [Financial management of the regional division city (on example of Košice town)], (in:) Teória a prax verejnej správy [Theory and practice of public administration] Košice: Pavol Jozef Šafárik University in Košice, 2018. pp. 180-189,

Available at: https://unibook.upis.sk/img/cms/2018/fvs/tvs2018-web.pdf.

Pahl, B., Mariański, M.: Issues Related to Wind Power Plants Taxation. A Comparative Analysis Based on French Tax Law Regulations, pp. 411-426 (in:) Mrkývka, P., Gliniecka, J., Tomášková, E., Juchniewicz, E., Sowiński, T., Radvan, M. (eds.) The Financial Law Towards Challenges of the XXI Century. Brno: Masaryk University Press, 2020. 
Podrimavský, M. et al.: Dejiny Slovenska III [History of Slovakia III], Bratislava: Veda, vydavatel'stvo SAV, 1992.

Radvan, M.: Místní daně [Local Taxes]. Praha: Wolters Kluwer ČR, 2012.

Radvan, M.: Article 9 of the European Charter of Local Self-Government in the Czech Republic, Financial Law Review, nr 4 [2], 2017, pp. 7-21. DOI 10.4467/22996834FLR.17.011.9039.

Románová, A., Červená, K.: Current System of Funding of Local Self-Government in Slovakia and its Challenge, Financial Law Review, $\mathrm{nr} 4$ [2], 2017, pp. 45-56. DOI 10.4467/22996834FLR.17.015.10333.

Slovinský, A., Girášek, J.: Českoskovenské finančné právo [Czechoslovak Financial Law], Bratislava: Obzor, 1974.

Vartašová, A., Červená, K.: Views on Quality of Tax Regulation in the Slovak Republic (Focused on Real Property Taxation), Praha: Leges, 2019.

Vernarský, M.: Samospráva obce pri ukladaní dane z nehnutel'ností [Self-governance of municipality in imposing the real estate tax], (in:) Palúš I., Mital' O., Žofčinová V. (eds.): Verejná správa v súčasnom demokratickom a právnom štáte (čast' 1.) [Public administration in current democratic and legal state (Part 1)] Košice: Pavol Jozef Šafárik University in Košice, 2018. pp. 255-266.

\section{Legal Acts}

Act No. 582/2004 Coll. on Local Taxes and Local Charge for Municipal Waste and Minor Construction Waste as amended.

Generally binding regulation of the City of Košice No. 71 on local taxes as amended Available at: https://www.kosice.sk/vzn, accessed: $15^{\text {th }}$ July 2020.

Generally binding regulation of the City of Košice No. 132 on local taxes as amended Available at: https://www.kosice.sk/vzn, accessed: $15^{\text {th }}$ July 2020.

\section{Other official documents}

Mesto Košice: Záverečné účty mesta Košice [Final accounts of the city of Košice], roky 2009-2019 [years 2009-2019]

Available at:

https://www.kosice.sk/obcan/programovy-rozpocet-mesta-kosice-zaverecny-ucet-avyrocna-sprava-archiv, accessed: $10^{\text {th }}$ July 2020.

Mesto Košice: Hodnotiaca správa programového rozpočtu mesta Košice [Evaluation report of the program budget of the city of Košice], roky 2009-2019 [years 2009-2019]

Available at:

https://www.kosice.sk/obcan/programovy-rozpocet-mesta-kosice-zaverecny-ucet-avyrocna-sprava-archiv, accessed: $10^{\text {th }}$ July 2020.

Mesto Košice: Programový rozpočet mesta Košice na roky 2020 - 2022 [Program budget of the city of Košice for the years 2020 - 2022]

Available at:

https://www.kosice.sk/obcan/programovy-rozpocet-mesta-kosice-zaverecny-ucet-avyrocna-sprava-archiv, accessed: $10^{\text {th }}$ July 2020.

Mesto Košice: Údaje za roky 2005-2008 poskytnuté na vyžiadanie v zmysle zákona č. 211/2000 Z. z. o slobodnom prístupe $\mathrm{k}$ informáciám $\vee$ znení neskorších predpisov [Data for the years 2005-2008 provided upon request in accordance with Act No. 211/2000 Coll. on free access to information as amended], Magistrát mesta Košice, 2020.

\section{Internet Resources}

E-obce.sk: Košice - História [Košice - History]

Available at: https://www.e-obce.sk/obec/kosice/2-historia.html, accessed: $10^{\text {th }}$ July 2020.

Mesto Košice: $Z$ histórie mesta Košice - 14. Storočie [From the history of the city of Košice $-14^{\text {th }}$ Century]

Available at: https://www.kosice.sk/mesto/z-historie-mesta-kosice-14-storocie, accessed: $10^{\text {th }}$ July 2020. 
Mesto Košice: Z histórie mesta Košice -13 . Storočie [From the history of the city of Košice $-13^{\text {th }}$ Century]

Available at: https://www.kosice.sk/mesto/z-historie-mesta-kosice-13-storocie, accessed: $10^{\text {th }}$ July 2020.

Mesto Košice: Základná charakteristika - demografické údaje [Basic characteristics - demographic data]

Available at: https://www.kosice.sk/mesto/zakladna-charakteristika-demograficke-udaje, accessed: 10th July 2020. 